\title{
Phenotype and genotype variability of interspecific rice lines related to bacterial leaf blight resistance (Xanthomonas oryzae pv. oryzae) character
}

\author{
SITI YURIYAH ${ }^{1,2, \bullet}$, DEDY DARNAEDI ${ }^{1}$, TATANG MITRA SETIA ${ }^{1}$, GUT WINDARSIH ${ }^{3}$, \\ DWINITA WIKAN UTAMI ${ }^{2}$ \\ ${ }^{1}$ Program of Biology, Graduate School, Universitas Nasional. Jl. Sawo Manila, Pejaten, Pasar Minggu, South Jakarta 12520, Jakarta, Indonesia \\ Tel.: +62-21-7806700 (hunting) ext. 24, Fax.: +62-21-7806462, `email: sitiyuriyah2@ gmail.com \\ ${ }^{2}$ Indonesian Center of Biotechnology and Agricultural Genetic Resources for Research and Development. J1.Tentara Pelajar 3A, Bogor 16111, West Java, \\ Indonesia \\ ${ }^{3}$ Program of Biology, Faculty of Science, Universitas Islam Negeri Sultan Maulana Hasanuddin Banten. Jl. Syech Nawawi Al Bantani, Andamu’i, Curug, \\ Serang City 42116, Banten, Indonesia
}

Manuscript received: 30 July 2021. Revision accepted: 1 September 2021.

\begin{abstract}
Yuriyah S, Darnaedi D, Setia TM, Windarsih G, Utami DW. 2021. Phenotype and genotype variability of interspecific rice lines related to bacterial leaf blight resistance (Xanthomonas oryzae pv. oryzae) character. Biodiversitas 22: 4123-4130. Wild rice species are the source of the gene pool for rice genetic diversity. The cross-species crosses (interspecific crosses) play an important role in breeding, namely in terms of expanding the diversity of desirable characters, such as disease resistance and improvement in yield potential. Currently, the genes from wild rice species have been successfully introgressed into cultivated rice so that they can overcome the rice production constraints, including the introgression of genes for the bacterial leaf blight (BLB) resistance. The purpose of this study was to analyze the variability of phenotype and genotype performance of lines derived from wild rice species for the character of resistance to BLB disease. A total of 33 selected backcross lines derived from wild rice species of $O$. rufipogon and O. glaberrima as the donor parents and 2 control varieties (resistant and susceptible to BLB disease), were used in this study. The evaluation of phenotype and genotype of resistance characters to BLB disease was carried out during a vegetative phase of the plant. The resistance e valuation was carried out in a greenhouse, while the genotype performance was analyzed using 4 STS markers linked to $\mathrm{Xa}$, $\mathrm{Xa}$, and $\mathrm{Xa13}$ genes. The result of the phenotype evaluation showed that there were variations among the resistance of the tested lines. Three lines derived from a Situ Bagendit/Oryza rufipogon cross were resistant to all BLB races used in the testing. Those three lines indicated to have the allele of the $X a 7$ resistance gene based on the genotype performance which grouped with the Code variety that had the $X a 7$ resistance gene.
\end{abstract}

Keywords: Bacterial leaf blight resistance, molecular markers selection, wild rice species

\section{INTRODUCTION}

Rice (Oryza sativa L.) is a leading staple worldwide. The global food demands require the cultivation of highquality and high-yield rice varieties that are resistant to multiple diseases. However, rice domestication resulted in the reduction of genetic diversity, and the 1990s saw a marked decline in yield growth rate (Badawi 2004). To increase the genetic diversity of rice, the breeders have focused on identifying the genes responsible for desirable traits in the relatives of cultivated rice varieties and transferring those genes to $O$. sativa. Wild rice is a relative of cultivated rice $(O$. sativa) with specific morphological characters and potential as a gene source for rice breeding (Atwell et al. 2014). Wild rice has various important characteristics that are not owned by cultivated rice, such as the resistance to pests and diseases and the tolerance to environmental stresses, such as drought and inundation. Therefore, wild rice is useful as a source of genes for character improvement in breeding programs (Suhartini 2016). Some wild rice species include: (i) Oryza rufipogon distributed in Australia and Asia, and (ii) Oryza glaberrima from West Africa which has a strong stem character, productive tillers, a large number of grains per panicle, and plants can be ratooned. Oryza glaberrima originates from the Niger River delta, the main point of $O$. glaberrima diversity is a swamp basin in the upper Niger River and the second point is in the southwest near the Guinean Coast (Dogara and Jumare 2014; Champion et al. 2021). Indonesia is one of the important regions that have a diversity of wild rice relatives, it is necessary to prioritize conservation to have a stock of quality and sustainable wild rice seeds (Rahman et al. 2019).

Several kinds of research showed that wild rice species potentially as genetic resources for increased BLB resistance on rice, such as $O$. latifolia (Angeles-Shim et al. 2014), O. longistaminata, O. rufipogon and O. minuta (Vikal and Bhatia 2017). Oryza rufipogon was also reported that found have the broad-spectrum resistance to Philippine and Indian BLB races (Ram et al. 2011). Twenty-eight accessions from $O$. glaberrima species and 2 accessions from $O$. rufipogon species resistant to Xoo pathotypes $\mathrm{PbXo-} 8$, and 8 accessions from $O$. rufipogon species resistant to Xoo pathotypes $\mathrm{PbXo-10}$ (Neelam et al. 
2016). A total of 16 markers which are linked to the $X a 5$, $X a 10, X a 13$, and $X a 21$ genes had been successfully used to obtain potential, fast, easy and consistent varieties in marker-assisted selection (MAS) to be used in a breeding program of BLB resistant rice resulted from a crossing between the MR219 race from Malaysia with IRBB60 (Zuki et al. 2020).

Interactions between rice and Xanthomonas oryzae pv. oryzae (Xoo) have become important models for understanding the fundamental aspects of plant disease resistance and bacterial pathogenesis, as well as other aspects of plant and microbial biology, with implications for innate animal immunity too (Niño-Liu et al. 2006). Xa4 gene mediates a race-specific and durable resistance to Xoo at all stages of rice growth in many countries (Webb et al. 2010). Xa4 gene was first incorporated into commercial rice varieties in the early 1979 s and has been one of the most widely exploited resistance genes in breeding programs in at least 54 Asian, African, South American, and Mesoamerican countries (Khush and Virk 2005).

$\mathrm{Xa} 7$ gene is well known for conferring durable resistance against bacterial leaf blight, which has been verified by a 10-year cropping period (Webb et al. 2010). Furthermore, increased effectiveness has been reported for $X a 7$-mediated resistance under high temperature and drought stresses (Dossa et al. 2020). These features lend great importance to the functional study of this gene. $\mathrm{Xa} 7$ gene was originally identified from rice variety of DV85 (Sidhu et al. 1978) and introduced into the near-isogenic line of IRBB7 through multiple rounds of backcrossing of DV85 with IR24 as a recurrent parent (Ogawa et al. 1991). The recessive resistance gene of Xa13 occurs as a series of natural alleles of the susceptible gene of $O s-8 N 3$, whose expression is induced by strains of Xanthomonas oryzae pv. oryzae carrying the gene of PthXol, which encodes the transcription activator-like (TAL) effector of PthXol (Yuan et al. 2009).

The use of wild rice in rice breeding is often hampered by the introgression of target genes from wild rice to cultivated rice, especially for wild rice species which have different genome types from cultivated rice. However, through the molecular biology technologies, such as the use of molecular markers, this obstacle can be overcome, so that the gene transfer from wild rice to cultivated rice can be carried out. The availability of linkage maps of molecular markers with gene loci for target characters can assist in tracking introgressions and desirable characters and avoiding unwanted introgressions (Neelamraju and Swamy 2014). The objectives of this study were to analyze the variability of phenotype and genotype performance of wild rice species for the character of resistance to BLB disease and clustered them to found the resistance pattern to the three major BLB races used for screening.

\section{MATERIALS DAN METHODS}

\section{Genetic materials}

The genetic materials used in this study amounted to 33 lines of advanced backcross and selling on third $\left(\mathrm{BC}_{5} \mathrm{~F}_{3}\right)$ crossing between $O$. rufipogon (acc. IRGC105491) and $O$. glaberrima (acc. IRGC100156) with several superior varieties, such as Ciherang, Inpari 10, Inpari 13 and Situ Bagendit. These populations are developed to support the BB Biogen breeding program by national funding. For the resistance performance comparison, several control varieties were used in this study: Code and $\mathrm{TN}-1$ as resistant and susceptible control varieties, respectively; Ciherang, Inpari 10, and Situ Bagendit as parents control plants; monogenic lines (IRBB4, IRBB5, IRBB7, IRBB13, IRBB21); and the two varieties of Code and Angke as the control varieties which contained the resistance genes incorporated. The total genetic materials of this research were showed in Table 1.

Meanwhile, the BLB isolates used for resistance evaluation were pure isolates cultures of races III, IV, and VIII, as the BLB's dominant races in BLB endemic locations (Yuriyah et al. 2013). The purebred cultures used were the collection of the Center for Research and Development on Biotechnology and Agricultural Genetic Resources (ICABIOGRAD) (Table 2).

\section{Phenotype variability analysis}

$B L B$ resistance evaluation

The BLB resistance was evaluated at the ICABIOGRAD's greenhouse condition. The seeds of rice lines screened were oven-dried for \pm 12 hours at $50^{\circ} \mathrm{C}$, the seeds were germinated on wet tissue in a petri dish. Seven days later, the seedlings were planted at a spacing of $4 \mathrm{~cm}$ $\times 2 \mathrm{~cm}$ in a plastic tub measuring $31 \mathrm{~cm}$ in width, length 39 $\mathrm{cm}$, and height $12.5 \mathrm{~cm}$, containing a mixture medium of silt and manure (10:1). Each tub was planted with 20 lines in rows and six seeds were planted for each accession. The resistant, susceptible, and monogenic control varieties were grown in each tub. For each BLB race, there were three replications. Bacterial inoculum was cultured on $20 \mathrm{~mL}$ of Wakimoto's agar medium or WF-P medium in a petri dish for 48 hours at $28-30^{\circ} \mathrm{C}$. Bacterial cultures were added with $10 \mathrm{~mL}$ of sterile distilled water, stirred using a sterile skewer until homogeneous, and the concentration was measured using a spectrophotometer, then diluted to a concentration of $10^{8} \mathrm{cfu}$. The plants that were 30 days after planting (DAP) were inoculated by cutting the tips of the leaves along $0.5-1.0 \mathrm{~cm}$ using a sterile scissor that had been dipped in the inoculum. The plants were incubated in a greenhouse and kept for the humidity by spraying water with a sprinkler starting from one day after inoculation (Yuriyah et al. 2013).

The observation was conducted on the $14^{\text {th }}$ day after inoculation by measuring the length of the third and fourth leaves of the flag leaf and the length of the attack symptom $(\mathrm{cm})$. The disease intensity (DI) was calculated using the formula of DI $=\mathrm{LS} / \mathrm{LOL} \times 100 \%$, where $\mathrm{LS}=$ length of symptom and TLL $=$ total leaf length (Yuriyah et al. 2016). The determination of the level of resistance was carried out according to criteria modified from the Standard Evaluation System for Rice (IRRI 2013), with DI = disease intensity, $\mathrm{R}=$ resistant $(\mathrm{DI} \leq 25 \%), \mathrm{S}=$ susceptible $(\mathrm{DI} \geq 25)$. 
Table 1. The genetic materials that used in the testing of lines derived from the crosses of superior varieties with wild rice species

\begin{tabular}{|c|c|c|c|}
\hline $\begin{array}{c}\text { Line } \\
\text { number }\end{array}$ & Lines & Parents or control varieties & Population or lines \\
\hline 1 & 1-F-C21 & Inpari 10/Oryza glaberrima & $\mathrm{BC}_{5} \mathrm{~F}_{3}$ \\
\hline 2 & 2a-F-C21 & & \\
\hline 3 & 2b-F-C21 & & \\
\hline 4 & 7-F-C1 & Ciherang/Oryza rufipogon & $\mathrm{BC}_{5} \mathrm{~F}_{3}$ \\
\hline 5 & $59-\mathrm{F}-\mathrm{C} 21$ & & \\
\hline 6 & 69-F-C21 & & \\
\hline 7 & 103a-F-C21 & & \\
\hline 8 & 103b-F-C21 & & \\
\hline 9 & $12-\mathrm{F}-\mathrm{C} 21$ & Inpari 13/Oryza rufipogon & $\mathrm{BC}_{5} \mathrm{~F}_{3}$ \\
\hline 10 & $25-\mathrm{F}-\mathrm{C} 21$ & & \\
\hline 11 & $71-\mathrm{F}-\mathrm{C} 21$ & & \\
\hline 12 & $86-\mathrm{F}-\mathrm{C} 21$ & & \\
\hline 13 & 22-F-C21 & Situ Bagendit/Oryza rufipogon & $\mathrm{BC}_{5} \mathrm{~F}_{3}$ \\
\hline 14 & $32-\mathrm{F}-\mathrm{C} 21$ & & \\
\hline 15 & 37-F-C21 & & \\
\hline 16 & 44-F-C21 & & \\
\hline 17 & $48-\mathrm{F}-\mathrm{C} 21$ & & \\
\hline 18 & $51-\mathrm{F}-\mathrm{C} 21$ & & \\
\hline 19 & $54-\mathrm{F}-\mathrm{C} 21$ & & \\
\hline 20 & $58-\mathrm{F}-\mathrm{C} 21$ & & \\
\hline 21 & $81-\mathrm{F}-\mathrm{C} 21$ & & \\
\hline 22 & $89-\mathrm{F}-\mathrm{C} 21$ & & \\
\hline 23 & Ciherang & Reccurent parent control variety & Elite/popular lowland variety \\
\hline 24 & Inpari 13 & Reccurent parent control variety & \\
\hline 25 & Inpari 10 & Reccurent parent control variety & \\
\hline 26 & Situ Bagendit & Reccurent parent control variety & Elite/popular upland variety \\
\hline 27 & Angke & Control varieties contained $\mathrm{X} a 4+\mathrm{X} a 5$ genes & Elite/popular lowland variety \\
\hline 28 & Code & Control varieties contained $\mathrm{X} a 4+\mathrm{X} a 7$ genes & Elite/popular lowland variety \\
\hline 29 & $\mathrm{TN}-1$ & BLB susceptible control variety & Introduction variety from China \\
\hline 30 & Kencana Bali & BLB susceptible control variety & Local variety \\
\hline 31 & IRBB4 & Monogenic line contained $\mathrm{Xa} 4$ gene as control variety & Introduction varieties from IRRI* \\
\hline 32 & IRBB5 & Monogenic line contained $\mathrm{X} a 5$ gene as control variety & Introduction varieties from IRRI* \\
\hline 33 & IRBB7 & Monogenic line contained $\mathrm{Xa} 7$ gene as control variety & \\
\hline 34 & IRBB13 & Monogenic line contained $\mathrm{Xa} 13$ gene as control variety & \\
\hline 35 & IRBB21 & Monogenic line contained $\mathrm{Xa21}$ gene as control variety & \\
\hline
\end{tabular}

Note: *IRRI: International Rice Research Institute

\section{Genotype variability analysis \\ DNA isolation}

The leaf samples were taken from each tested plant aged 30 days before being inoculated in a greenhouse using the tested races. The DNA isolation procedure was carried out using a modified cetyltrimethylammonium bromide (CTAB) extraction buffer (Rani and Sharma 2016). The ingredients for the extraction buffer were CTAB $2 \%(\mathrm{w} / \mathrm{v})$, Tris- $\mathrm{HCl} 100 \mathrm{mM}(\mathrm{pH} 8.0), \mathrm{NaCl} 1.4 \mathrm{M}$, and EDTA 20 $\mathrm{mM}$ (pH 8.0). A total of 0.5 grams of leaf pieces was crushed using an extraction buffer, then the sample was extracted twice using chloroform: isoamyl alcohol (24:1). A dried DNA pellet was dissolved with TE buffer (Tris 10 $\mathrm{mM}$ [pH 8.0], EDTA $1 \mathrm{mM})$. The stock DNA solution obtained was tested qualitatively and quantitatively to determine its quality and concentration. The quantitatively testing was carried out using a NanoDrop ${ }^{\text {TM }} 2000$ spectrophotometer (Thermo Scientific, USA), while the qualitatively testing was carried out using an electrophoresis on $1 \%$ agarose gel. The results of electrophoresis were observed under UV light on a UV TransIlluminator (UVP, UK).
PCR analysis using STS markers-based genes for markerassisted selection

The molecular markers used to identify the genes for resistance to BLB disease in tested lines were the STS (Sequence-Tagged Sites) markers. These markers are flanking markers for detecting the genes for resistance to BLB disease, which are linked to $\mathrm{Xa4}, \mathrm{Xa} 7$ and $\mathrm{Xa} 13$ genes (Table 3) and to be known to cosegregate with the genes for resistance to BLB disease (Winandari et al. 2014; NanJiang et al. 2020).

The DNA sequence of 4 pairs of STS primers used in the study was shown in Table 3. The genomic DNA was diluted at a concentration of $10 \mathrm{ng} / \mu \mathrm{L}$ which was used as a template for the PCR reaction. The PCR mixture was prepared with a composition of $2 \mu \mathrm{L}$ DNA $(10 \mathrm{ng} / \mu \mathrm{L}), 2$

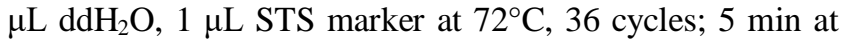
$72^{\circ} \mathrm{C}$. Electrophoresis of PCR products was carried out on $2 \%$ agarose gel with 24 wells. In each well, a mixture of 1 $\mu \mathrm{L}$ loading dye and GelRed® Nucleic Acid Gel Stain (Biotium, USA): ddH2O (1:2), and $2 \mu \mathrm{L}$ PCR product was added. Electrophoresis was carried out with an electric current of 90 Volts for 1 hour. The DNA bands were visualized using a ChemiDoc $\mathrm{EQ}^{\mathrm{TM}} \mathrm{UV}$ transilluminator (Bio-Red Gel Doc EZ Imager) and scored by size. 
Table 2. The list of Xanthomonas oryzae pv. oryzae races that used in this study

\begin{tabular}{ccccc}
\hline Races & ID Number & Year of Collection & Origin of Isolate & Location \\
\hline III & IXO 18-AgN-3 & 2018 & Jatisari, Cikampek & West Java \\
IV & IXO 76-002 & 1980 & local Cianjur & West Java \\
VIII & IXO 79-008 & 1980 & Siyam Halus & Banjarmasin, Kalimantan \\
\hline
\end{tabular}

Table 3. The primers used to amplify the molecular marker linked to the resistance gene to BLB disease

\begin{tabular}{|c|c|c|c|c|c|c|c|}
\hline \multirow{2}{*}{ Primers } & \multirow{2}{*}{$\begin{array}{c}\text { Gene } \\
\text { marker }\end{array}$} & \multirow{2}{*}{$\begin{array}{l}\text { Marker } \\
\text { type }\end{array}$} & \multirow{2}{*}{ Chr. } & \multicolumn{2}{|c|}{ Sequences } & \multirow{2}{*}{$\begin{array}{c}\text { Temp. of } \\
\text { Annealing } \\
\left({ }^{\circ} \mathrm{C}\right)\end{array}$} & \multirow{2}{*}{$\begin{array}{c}\text { Band } \\
\text { size (bp) }\end{array}$} \\
\hline & & & & Forward (5'-3') & Reverse (5'-3') & & \\
\hline Xa4LD5 & Xa4 & STS & 11 & CACGTCATGCCTCTTGCTTA & CAGAGGACAACAGCGAACAA & 55 & 183 \\
\hline Xa4LD6 & Xa4 & STS & 11 & AGCGCGCTTTCCTATTTACA & CCGAGAGGAAGTCTGACTGG & 55 & 253 \\
\hline Xa7LD34 & $X a 7$ & STS & 6 & GTGTTTGCTACGTATGGATG & GAGTGATGGTCTTTCCTGTC & 55 & 741 \\
\hline Xa13LD59 & Xal3 & STS & 8 & CAGCGCGTAGAAGATCCACA & ATGGCACAAGTCACTTCCC & 55 & 672 \\
\hline Xa13LD60 & Xa13 & STS & 8 & AATCAAGTCGTTGGCACTGG & CCATCGCTGGTCCGTCTAAG & 55 & 753 \\
\hline
\end{tabular}

Note: Chr.: chromosome

\section{Data analysis}

The electrophoresis results on $2 \%$ agarose gel (Figure 2) were scored as binary data. Each primer used by comparing the size of the DNA bands in the entire samples was considered as one allele. The DNA bands that had the same migration rate were considered to have the same locus. The visible band was given a score of 1 , the invisible band was given a score of 0 , while the sample that did not produce an amplicon was given a score of 9 and was considered as missing data. The scoring results were in the form of binary data.

In both data sets, phenotype and genotype data, the association analysis was carried out using TASSEL software to determine a relationship between the two data. The analysis of phenotype diversity was shown as a dendrogram of resistance on tested lines that were resistant to races III, IV and VIII.

\section{RESULTS AND DISCUSSION}

\section{Phenotype variability on BLB resistance character}

The wild rice species have been recognized as the rich reservoir gene pool of novel genes underlying important agronomic traits, including tolerance to abiotic stress, as well as resistance to a wide range of pests and diseases (Brar and Khush 2017). Several wild rice species have introgressed to $O$. sativa for varietal improvement purposes (Angeles-Shim et al. 2014; Ramos et al. 2016).

One of the wild rice species, O. rufipogon was the potential gene pool as the genetic source for BLB resistance character (Singh et al. 2015). A total of $33 \mathrm{BC}_{5} \mathrm{~F}_{3}$ lines progenies from $O$. rufipogon have variation in their resistance to three BLB races used for screening in a greenhouse condition (Table 4). Three lines were resistant to three BLB races used, i.e. lines number 22, 44 and 54 with DI range between $6.69 \%$ to $22.35 \%$. These three lines are progenies from a crossing between Situ Bagendit and O. rufipogon. Among those three lines, line 44 was the most resistant to races III, IV and VIII of BLB pathogen tested, with DI $8.85 \%, 7.91 \%$, and $13.08 \%$, respectively.

Among the tested lines, line 54 was the most resistant to race III, which had the lowest DI $(6.74 \%$, Figure 1$)$. Meanwhile, lines 59 and 103a, as progenies from Ciherang and $O$. rufipogon, were the most resistant to race IV, with a DI range between $3.54 \%$ to $3.58 \%$. The control resistant varieties (Angke, Code, IRBB4, IRBB5, IRBB7, IRBB21) were resistant to all three races which their DI ranged between $3.27 \%$ to $24.10 \%$. While, the donor parents, Ciherang and Situ Bagendit varieties, were resistant to races III and IV. Inpari 13 and Inpari 10 were resistant to three BLB races used. The resistance performance of lines tested were showed in Figure 1.

The resistance response of three tested lines 22, 44 and 54 were resistant to three BLB races used and derived from a cross between the parents of Situ Bagendit and $O$. rufipogon. Meanwhile, the Situ Bagendit variety was resistant to races III and IV but susceptible to race VIII. These results indicate that in those three tested lines, there is introgression of resistance character to race VIII from the parent of $O$. rufipogon.

Line 59 showed the most resistance to race IV, indicated by the smallest DI of $3.54 \%$ compared to other lines tested. Line 59 is the progeny from a cross between Ciherang and $O$. rufipogon. The resistance response of line 59 compared to its parent, Ciherang variety, was not different, susceptible to race VIII. However, line 59 showed an increase in resistance to race IV, with DI of $3.54 \%$, lower than its parent, Ciherang, which reached $7.17 \%$.

Currently, nine groups of BLB races in Indonesia have been identified (Utami et al. 2010). Among these races, race IV is a virulence group. Meanwhile, based on the distribution, BLB races III, IV and VIII have the most widespread distribution and are dominant in several endemic locations of BLB disease in Indonesia (Yuriyah 2015). 


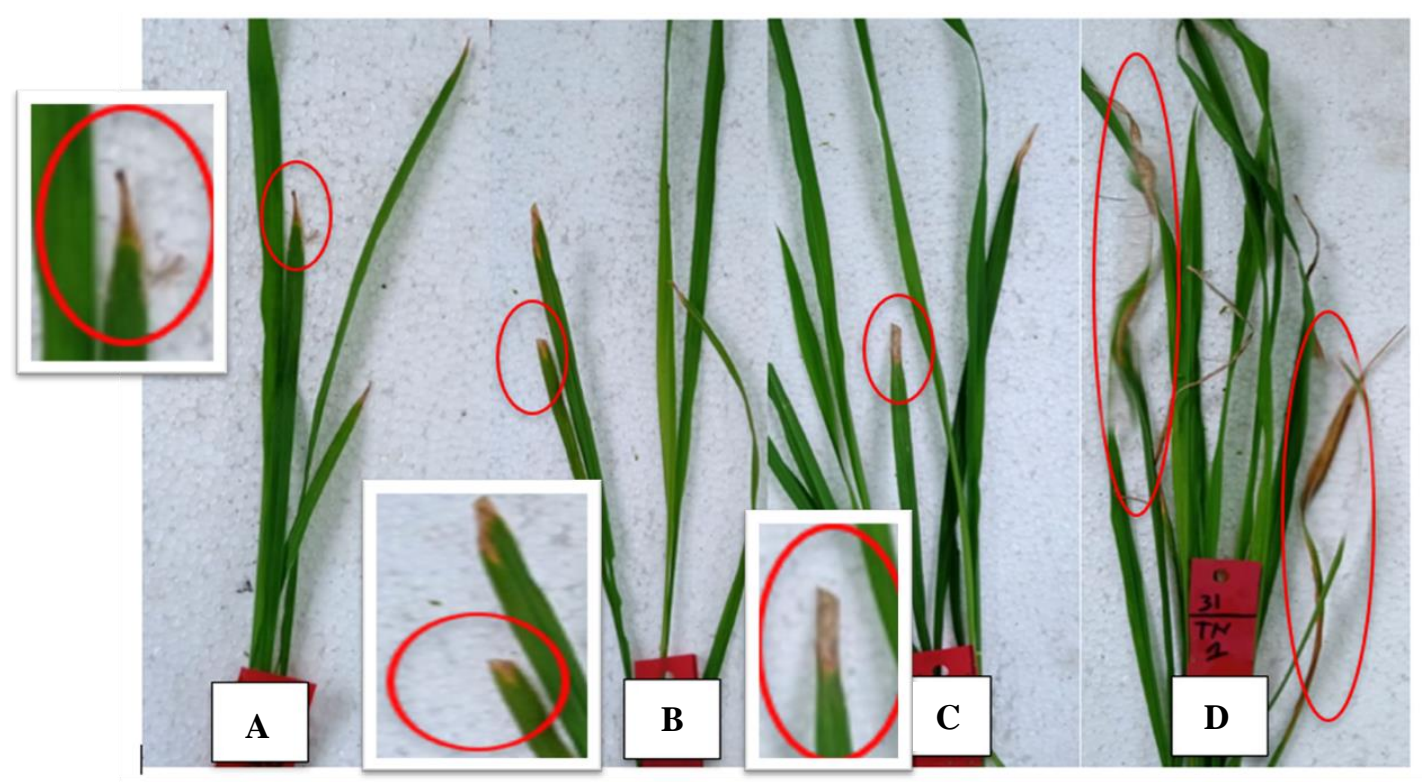

Figure 1. The resistance response performance. A. Original number line 54, B. Control resistant variety of Angke, C. Line IRBB4 that resistant to three BLB races, and D. TN-1 susceptible to three BLB races

Table 4. The resistance response of lines derived from crosses of varieties with wild rice in vegetative phase

\begin{tabular}{|c|c|c|c|c|c|c|c|}
\hline \multirow{2}{*}{ Line number } & \multirow{2}{*}{ Lines } & \multicolumn{2}{|c|}{ Race III } & \multicolumn{2}{|c|}{ Race IV } & \multicolumn{2}{|c|}{ Race VIII } \\
\hline & & DI (\%) & Response & DI (\%) & Response & DI (\%) & Response \\
\hline 1 & 1-F-C21 & 12.70 & $\mathrm{R}$ & 12.97 & $\mathrm{R}$ & 46.35 & S \\
\hline 2 & 2a-F-C21 & 20.51 & $\mathrm{R}$ & 30.22 & $\mathrm{~S}$ & 40.51 & $\mathrm{~S}$ \\
\hline 3 & 2b-F-C21 & 9.74 & $\mathrm{R}$ & 29.67 & $\mathrm{~S}$ & 33.44 & $\mathrm{~S}$ \\
\hline 4 & $7-\mathrm{F}-\mathrm{C} 1$ & 9.14 & $\mathrm{R}$ & 7.07 & $\mathrm{R}$ & 31.50 & S \\
\hline 5 & 59-F-C21 & 9.65 & $\mathrm{R}$ & 3.54 & $\mathrm{R}$ & 33.16 & S \\
\hline 6 & 69-F-C21 & 9.97 & $\mathrm{R}$ & 13.49 & $\mathrm{R}$ & 38.90 & S \\
\hline 7 & 103a-F-C21 & 7.29 & $\mathrm{R}$ & 3.58 & $\mathrm{R}$ & 28.38 & S \\
\hline 8 & 103b-F-C21 & 8.33 & $\mathrm{R}$ & 6.85 & $\mathrm{R}$ & 35.75 & S \\
\hline 9 & $12-\mathrm{F}-\mathrm{C} 21$ & 9.01 & $\mathrm{R}$ & 5.00 & $\mathrm{R}$ & 38.56 & S \\
\hline 10 & $25-\mathrm{F}-\mathrm{C} 21$ & 8.44 & $\mathrm{R}$ & 6.13 & $\mathrm{R}$ & 32.83 & $S$ \\
\hline 11 & $71-\mathrm{F}-\mathrm{C} 21$ & 10.30 & $\mathrm{R}$ & 10.92 & $\mathrm{R}$ & 35.40 & $S$ \\
\hline 12 & $86-\mathrm{F}-\mathrm{C} 21$ & 8.04 & $\mathrm{R}$ & 9.72 & $\mathrm{R}$ & 40.84 & $S$ \\
\hline 13 & 22-F-C21 & 15.99 & $\mathrm{R}$ & 6.82 & $\mathrm{R}$ & 21.36 & $\mathrm{R}$ \\
\hline 14 & $32-\mathrm{F}-\mathrm{C} 21$ & 17.55 & $\mathrm{R}$ & 6.75 & $\mathrm{R}$ & 28.25 & S \\
\hline 15 & $37-\mathrm{F}-\mathrm{C} 21$ & 20.24 & $\mathrm{R}$ & 8.36 & $\mathrm{R}$ & 37.80 & $S$ \\
\hline 16 & $44-\mathrm{F}-\mathrm{C} 21$ & 8.85 & $\mathrm{R}$ & 7.91 & $\mathrm{R}$ & 13.08 & $\mathrm{R}$ \\
\hline 17 & $48-\mathrm{F}-\mathrm{C} 21$ & 8.78 & $\mathrm{R}$ & 5.50 & $\mathrm{R}$ & 31.44 & S \\
\hline 18 & $51-\mathrm{F}-\mathrm{C} 21$ & 10.73 & $\mathrm{R}$ & 5.35 & $\mathrm{R}$ & 32.23 & S \\
\hline 19 & $54-\mathrm{F}-\mathrm{C} 21$ & 6.74 & $\mathrm{R}$ & 6.69 & $\mathrm{R}$ & 22.35 & $\mathrm{R}$ \\
\hline 20 & $58-\mathrm{F}-\mathrm{C} 21$ & 9.44 & $\mathrm{R}$ & 7.40 & $\mathrm{R}$ & 30.71 & S \\
\hline 21 & $81-\mathrm{F}-\mathrm{C} 21$ & 13.62 & $\mathrm{R}$ & 5.02 & $\mathrm{R}$ & 43.81 & S \\
\hline 22 & $89-\mathrm{F}-\mathrm{C} 21$ & 8.98 & $\mathrm{R}$ & 8.43 & $\mathrm{R}$ & 32.08 & $S$ \\
\hline 23 & Ciherang & 12.73 & $\mathrm{R}$ & 7.17 & $\mathrm{R}$ & 24.85 & S \\
\hline 24 & Inpari 13 & 8.03 & $\mathrm{R}$ & 2.74 & $\mathrm{R}$ & 20.43 & $\mathrm{R}$ \\
\hline 25 & Inpari 10 & 7.55 & $\mathrm{R}$ & 4.90 & $\mathrm{R}$ & 17.51 & $\mathrm{R}$ \\
\hline 26 & Situ Bagendit & 10.12 & $\mathrm{R}$ & 4.33 & $\mathrm{R}$ & 32.87 & S \\
\hline 27 & Angke $(X a 4+X a 5)$ & 10.04 & $\mathrm{R}$ & 6.92 & $\mathrm{R}$ & 4.24 & $\mathrm{R}$ \\
\hline 28 & Code $(X a 4+X a 7)$ & 13.14 & $\mathrm{R}$ & 7.11 & $\mathrm{R}$ & 15.31 & $\mathrm{R}$ \\
\hline 29 & $\mathrm{TN}-1$ & 13.28 & $\mathrm{R}$ & 52.10 & S & 46.16 & $\mathrm{~S}$ \\
\hline 30 & Kencana Bali & 18.30 & $\mathrm{R}$ & 42.34 & S & 29.32 & S \\
\hline 31 & IRBB4 & 15.92 & $\mathrm{R}$ & 6.14 & $\mathrm{R}$ & 11.31 & $\mathrm{R}$ \\
\hline 32 & IRBB5 & 6.98 & $\mathrm{R}$ & 11.79 & $\mathrm{R}$ & 24.10 & $\mathrm{R}$ \\
\hline 33 & IRBB7 & 5.49 & $\mathrm{R}$ & 11.60 & $\mathrm{R}$ & 3.27 & $\mathrm{R}$ \\
\hline 34 & IRBB13 & 8.97 & $\mathrm{R}$ & 38.20 & S & 33.41 & S \\
\hline 35 & IRBB21 & 5.33 & $\mathrm{R}$ & 20.89 & $\mathrm{R}$ & 16.11 & $\mathrm{R}$ \\
\hline
\end{tabular}




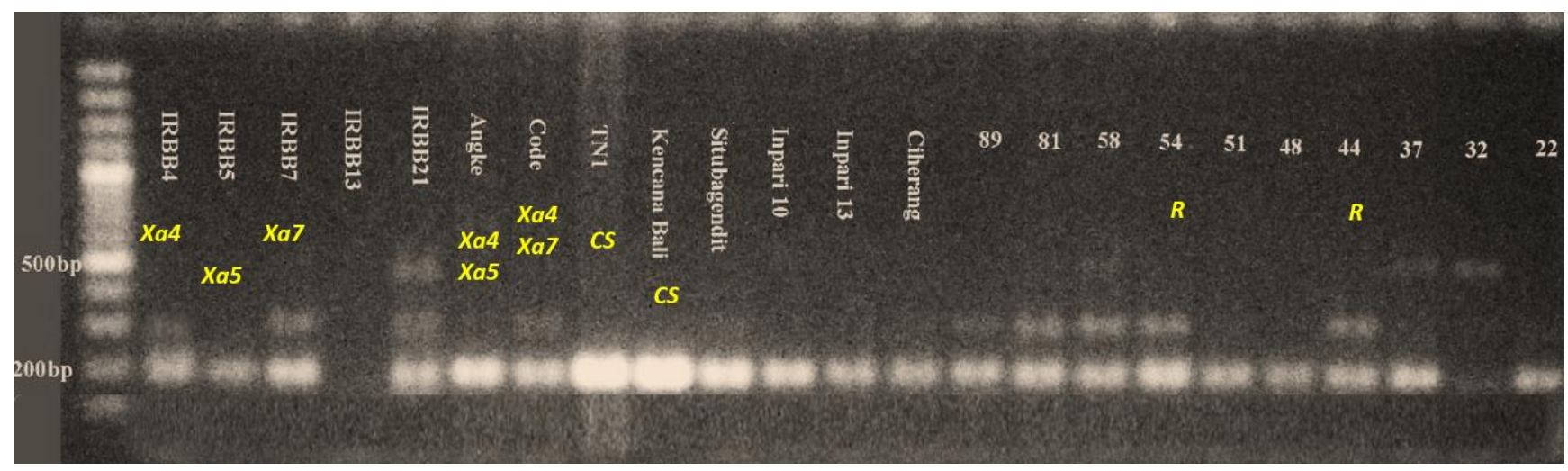

Figure 2. One of the genotype performance of PCR analysis using the Xa4LD5 marker which visualized on $2 \%$ gel agarose electrophoresis. Note: The yellow font are the genes contained in the monogenic lines and resistant control varieties, CS: the control varieties for susceptible character, Situ Bagendit (parent) and TN-1.

\section{Genotype variability based on STS markers for $\mathrm{Xa}$ genes}

The designed STS markers analysis used in this study was carried out based on the sequences of the target genes of $\mathrm{Xa} 4 \mathrm{X} \mathrm{X}$ 7, and $\mathrm{X} a 13$ have been known for the genetic maps in the rice genome. Xa4 gene was mapped on chromosome 11, at a position of 27.6-29.64 Mb. Xa7 gene was mapped on chromosome 6 , at a position of 27.37$28.10 \mathrm{Mb}$; while Xa13 gene was mapped on chromosome 8, at a position of 109.3-111.2 cm (Utami et al. 2010; www. gramene.org).

The one of genotype analysis performance of the lines using Xa4 gene based on STS markers, Xa4-LD5 marker, was showed in Figure 2. This result showed a polymorphism on bands size ranged between 200-500 base pairs (bp). The genotype performance of monogenic lines (IRBB4, IRBB5, IRBB7) and control varieties, Angke and Code were showed related to the gene contained (Xa4, Xa5 and $X a 7)$. Meanwhile, the susceptible control varieties, Code, Angke, and the superior parent varieties (Situ Bagendit, Inpari 10, Inpari 13, Ciherang) were polymorphisms to resistance lines 54 and 44, which resistant to three BLB races used based on phenotyping. The other lines, i.e. $89,81,58,37$, and 32 , which were resistant to the two races used showed a polymorphism also to the susceptible control varieties.

All tested lines showed in Figure 2 were derived from the $O$. rufipogon donor parent in crossing. It showed that the $O$. rufipogon wild rice-derived lines have diverse allele diversity of the $\mathrm{Xa} 4$ gene. The genotype diversity for the $X a 4$ gene allele in those $O$. rufipogon-derived lines correlated with the resistance response to race IV. The $O$. rufipogon-derived lines were more resistant to race IV than O. glaberrima-derived lines (results not showed). Thus, the diversity of alleles produced by the STS marker of Xa4LD5 can describe the character of resistance to BLB disease, especially to race IV.

\section{Phylogenetic analysis}

The phylogenetic cluster analysis was needed to identify the resistance pattern for the lines evaluated. Based on the phylogenetic cluster obtained, the estimation of the resistance pattern of lines tested could be compared to the control varieties which contained the identified resistance gene. The phylogenetic analysis was conducted for clustering all tested lines based on diverse alleles from genotyping analysis. In parallel, the result of phylogenetic cluster analysis was available to compare the BLB resistance performance of each line in each sub-cluster. The phylogenetic analysis was carried out based on variations in the size of the DNA bands obtained which were then analyzed based on the UPGMA (Unweighted Pair Group Method with Arithmetic Mean) approach. Furthermore, it was analyzed using TASSEL software to determine a relationship between the two data (Bradbury et al. 2007).

The results of the analysis showed that 22 tested lines, 13 parents, and control varieties were grouped into four main groups (Figure 3). The first group includes lines 7 , $59,69,103 \mathrm{a}$ and 103b which are derived from a cross between the Ciherang variety and $O$. rufipogon. The second group includes original line numbers $1,2 \mathrm{a}$ and $2 \mathrm{~b}$, which derived from a cross between Inpari 10 and $O$. glaberrima, line 25 derived from a cross between Inpari 13 and wild rice of $O$. rufipogon, and 2 monogenic control varieties of IRBB5 and IRBB4. The third group includes lines 71 and 12 which derived from a cross between Inpari 13 and $O$. rufipogon, as well as the control varieties of IRBB21 and IRBB13, it is suspected that the original line numbers 71 and 12 contain the BLB resistance genes of Xa21 and Xa13 that were contained in the monogenic lines of IRBB21 and IRBB13. The fourth group includes lines 89, 48, 22, 32, 37, $44,51,54,58$ and 81 which derived from a crossing between the Situ Bagendit variety and wild rice of $O$. rufipogon. However, there was line 86 which derived from a crossing between Inpari 13 and $O$. rufipogon. This group also includes several control varieties, i.e. IRBB7, Angke and Code. It is suspected that the lines in the fourth cluster contain the $\mathrm{Xa} 7$ gene because there was a control line of IRBB7 and the Code variety, which both control varieties contain the $\mathrm{Xa} 7$ gene. 


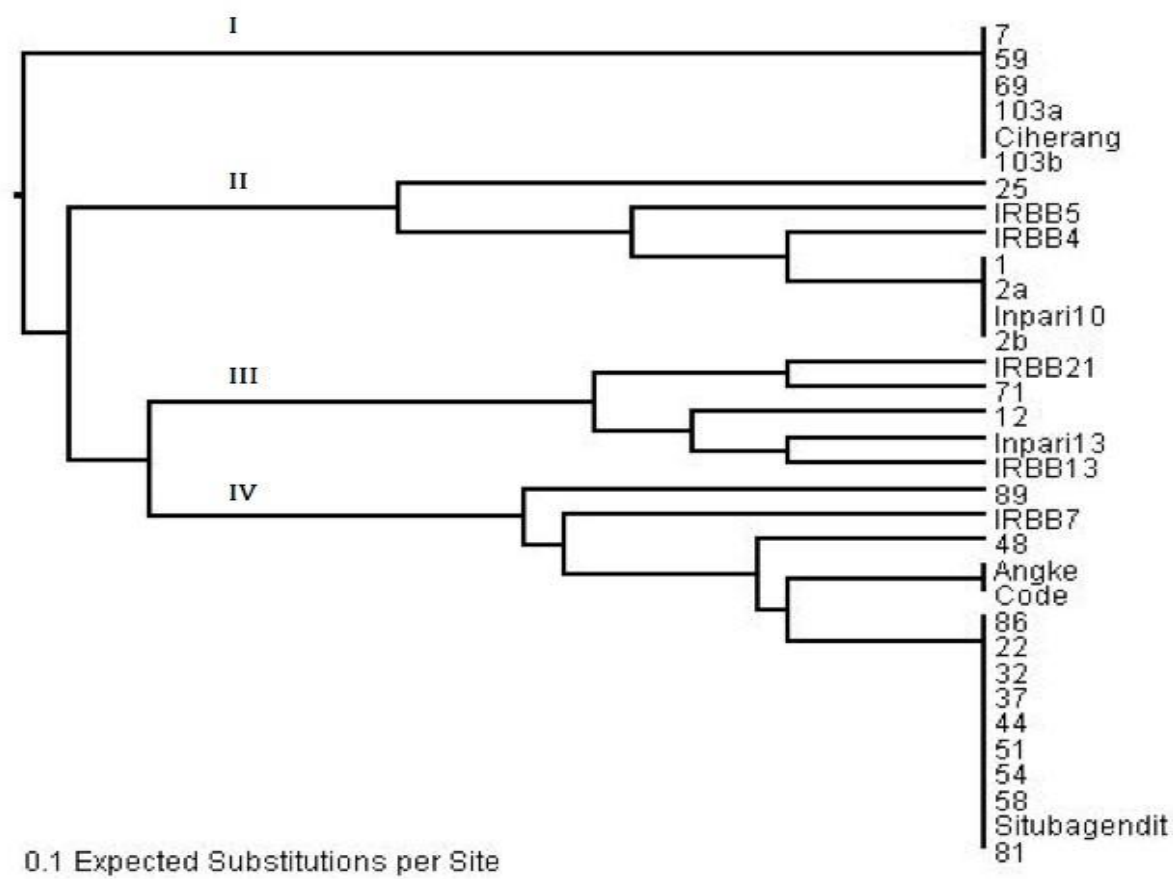

Figure 3. Dendrogram of scoring result using the STS markers of $\mathrm{Xa4}, \mathrm{Xa}$ and $\mathrm{Xal} 3$ genes linked to the resistance of rice lines to BLB disease

All lines analyzed were clustered based on the recurrent parent's genetic background. Group I consist of the tested lines derived from $O$. rufipogon where Ciherang as the recurrent parent; group II consists of the tested lines derived from $O$. glaberrima with the recurrent parent was Inpari 10; group III consists of the tested lines derived from O. rufipogon with the recurrent parent was Inpari 13; group IV consists of the tested lines derived from $O$. rufipogon with the recurrent parent was Situ Bagendit. The estimation pattern of BLB resistance contributed by the resistance genes on the lines tested was determined based on the similarity of the group with control varieties that were identified to have genes for resistance to BLB disease. Groups I and II had a genetic closeness to the control variety of IRBB4, indicated to have the allele of the Xa4 gene. The lines in group III had a genetic closeness to the control variety of IRBB13, indicated to have the allele of the Xa13 gene. Meanwhile, the lines in group IV had a genetic closeness to the control variety of IRBB7, indicated to have the allele of the $X a 7$ gene.

Based on the results of the study, the response of resistance of the lines derived from crosses between the varieties with the wild rice in a vegetative phase showed 3 original lines number 22, 44 and 54 which derived from a cross between Situ Bagendit and $O$. rufipogon being resistant to races III, IV and VIII with DI range of 6.69$22.35 \%$. These three lines indicated to have the allele of the $\mathrm{Xa} 7$ gene because based on the genotype performance, they were grouped with the Code variety that having the $\mathrm{Xa}$ 7 gene.

The STS markers used were able to be used to distinguish between the genotype performance of the resistant and susceptible lines. The lines analyzed showed an increased resistance compared to the superior varieties as the recurrent parents so that the lines used in this study were potentially to support the varieties improvement program.

\section{ACKNOWLEDGEMENTS}

We would like to thank The Indonesian Center for Agricultural Biotechnology and Genetic Resources (BBBiogen) for finding support of this research. Authors' contributions: SY and DWU: the main contributors who were responsible for designing the research, carrying out the experiments, analyzing-interpreting data, and writing the manuscript. DD, TMS: the contributor members who advising and supervising this research, and GW: the contributor members who supported wrote the manuscript.

\section{REFERENCES}

Angeles-Shim RB, Vinarao RB, Marathi B, Jena KK. 2014. Molecular analysis of Oryza latifolia Desv. (CCDD genome)-derived introgression lines and identification of value-added traits for rice $(O$. sativa L.) improvement. J Hered 105 (5): 676-689. DOI: 10.1093/jhered/esu032

Atwell BJ, Wang H, Scafaro AP. 2014. Could abiotic stress tolerance in wild relatives of rice be used to improve Oryza sativa? Plant Sci 215216: 48-58. DOI: 10.1016/j.plantsci.2013.10.007

Badawi AT. 2004. Ice-based production systems for food security and poverty alleviation in the Near East and North Africa. Int Rice Commun News1 53: 123-128.

Bradbury PJ, Zhang Z, Kroon DE, Casstevens TM, Ramdoss Y, Buckler ES. 2007. Tassel: Software for association mapping of complex traits in diverse samples. Bioinformatics 23 (19): 2633-2635. DOI: 10.1093/bioinformatics/btm308 
Brar D, Khush G. 2017. Alien introgression in rice. Nucleus 60: 251-261. DOI: $10.1007 / \mathrm{s} 13237-017-0222-7$

Champion L, Fuller DQ, Ozainne S, Huysecom É, Mayor A. 2021. Agricultural diversification in West Africa: An archaeobotanical study of the site of Sadia (Dogon Country, Mali). Archaeol Anthropol Sci 13: 60. DOI: 10.1007/s12520-021-01293-5

Dogara AM, Jumare AI. 2014. Origin, distribution and heading date in cultivated rice. Int J Plant Biol Res 2 (1).

Dossa GS, Quibod I, Atienza-Grande G, Oliva R, Maiss E, Cruz CV, Wydra K. 2020. Rice pyramided line IRBB67 (Xa4/Xa7) homeostasis under combined stress of high temperature and bacterial blight. Sci Rep 10. DOI: 10.1038/s41598-020-57499-5

IRRI [International Rice Research Institute]. 2013. Standard Evaluation System for Rice. International Rice Research Institute, Manila.

Khush GS, Virk PS. 2005. IR Varieties and Their Impact. International Rice Research Institute, Los Banos.

Nan-Jiang, Jun-Yan, Yi-Liang, Yanlong-Shi, Zhizhou-He, Yuntian-Wu, Qin-Zeng, Xionglun-Liu, Junhua-Peng. 2020. Resistance genes and their interactions with bacterial blight/leaf streak pathogens (Xanthomonas oryzae) in rice (Oryza sativa L.) - an updated review. Rice 13: 1-12. DOI: 10.1186/s12284-019-0358-y

Neelam K, Lore JS, Kaur K, Pathania S, Kumar K, Sahi G, Mangat GS, Singh K. 2016. Identification of resistance sources in wild species of rice against two recently evolved pathotypes of Xanthomonas oryzae pv. oryzae. Plant Genet Resour 15 (6): 558-562. DOI: $10.1017 / \mathrm{S} 1479262116000149$

Neelamraju S, Swamy BPM. 2014. Oryza glaberrima: A source for the improvement of Oryza sativa. Curr Sci 89 (6): 955-963.

Niño-Liu DO, Ronald PC, Bogdanove AJ. 2006. Pathogen profile Xanthomonas oryzae pathovars: Model pathogens of a model crop. Mol Plant Pathol 7 (5): 303-324. DOI: 10.1111/j.13643703.2006.00344.x

Ogawa T, Yamamoto T, Khush GS, Mew TW. 1991. Breeding of nearisogenic lines of rice with single genes for resistance to bacterial blight pathogen (Xanthomonas campestris pv. oryzae). Japanese J Breed 41: 523-529. DOI: 10.1270/jsbbs1951.41.523

Rahman W, Brehm JM, Maxted N. 2019. Setting conservation priorities for the wild relatives of food crops in Indonesia. Genet Resour Crop Evol 66: 809-824. DOI: 10.1007/s10722-019-00761-1

Ram T, Laha GS, Deen R, Ramos JM, Veracruz CM, Brar DS. 2011. Oryza rufipogon, a valuable source for resistance to bacterial blight of rice. Plant Breed 130 (6): 715-718. DOI: 10.1111/j.14390523.2011.01857.x

Ramos J, Furuta T, Uehara K, Chihiro N, Angeles-Shim R, Shim J. 2016 Development of chromosome segment substitution lines (CSSLs) of Oryza longistaminata A. Chev. \& Röhr in the background of the elite japonica rice cultivar, Taichung 65 and their evaluation for yield traits. Euphytica 210 (2): 151-163. DOI: 10.1007/s10681-016-1685-3
Rani B, Sharma VK. 2016. A modified CTAB method for quick extraction of genomic DNA from rice seed/grain/leaves for PCR analysis. Int J Sci Res Methodol 4 (4): 254-260.

Sidhu GS, Khush GS, Mew TW. 1978. Genetic analysis of bacterial blight resistance in seventy-four cultivars of rice, Oryza sativa L. Theor Appl Genet 53: 105-111. DOI: 10.1007/BF00272687

Singh AK, Dharmraj E, Nayak R, Singh PK, Singh NK. 2015. Identification of bacterial leaf blight resistance genes in wild rice of eastern India. Turk J Bot 39: 1060-1066. DOI: 10.3906/bot-1504-8

Suhartini T. 2016. Spesies padi liar (Oryza spp.) sebagai sumber gen ketahanan cekaman abiotik dan biotik pada padi budi daya. J Litbang Pertan 25 (4): 197-207. DOI: 10.21082/jp3.v35n4.2016.p197-207 [Indonesian]

Utami DW, Septiningsih EM, Kadir TS, Fatimah, Yuriyah S. 2010. Pencarian alel untuk identifikasi gen ketahanan penyakit hawar daun bakteri, $\mathrm{Xa} 7$ pada plasma nutfah padi lokal Indonesia. J AgroBiogen 6 (1): 1-9. DOI: 10.21082/jbio.v6n1.2010.p1-9 [Indonesian]

Vikal Y, Bhatia D. 2017. Genetics and genomics of bacterial blight resistance in rice. In: Li JQ (eds) Advances in International Rice Research. IntechOpen Limited, London. DOI: 10.5772/67361

Webb KM, Garcia E, Cruz CMV, Leach JE. 2010. Influence of rice development on the function of bacterial blight resistance genes. Eur $\mathbf{J}$ Plant Pathol 128: 399-407. DOI: 10.1007/s10658-010-9668-z

Winandari OP, Tjahjoleksono A, Utami DW. 2014. Identifikasi marka gen ketahanan hawar daun bakteri pada galur padi introduksi dan galur dihaploid. J Hama dan Penyakit Tumbuh Trop 14 (2): 101-109. DOI: 10.23960/j.hptt.214101-109 [Indonesian]

Yuan M, Chu Z, Li X, Xu C, Wang S. 2009. Pathogen-induced expressional loss of function is the key factor in race-specific bacterial resistance conferred by a recessive $\mathrm{R}$ gene $\mathrm{Xa13}$ in rice. Plant Cell Physiol 50 (5): 947-955. DOI: 10.1093/pcp/pcp046

Yuriyah S. 2015. Genetic diversity of Indonesian bacterial leaf blight isolate (Xanthomonas oryzae pv. oryzae ) core collection based on the VNTR and $a v r X a 7$ molecular markers. Makara J Sci 19 (3): 123-130. DOI: $10.7454 / \mathrm{mss} . v 19 \mathrm{i} 3.4893$

Yuriyah S, Nurani S, Utami DW, Silitonga TS. 2016. Evaluasi dan identifikasi marka penanda gen ketahanan penyakit hawar daun bakteri pada padi lokal Sulawesi Selatan. J AgroBiogen 12 (1): 11-20. DOI: 10.21082/jbio.v12n1.2016.p11-20 [Indonesian]

Yuriyah S, Utami DW, Hanarida I. 2013. Uji ketahanan galur-galur harapan padi terhadap penyakit hawar daun bakteri (Xanthomonas oryzae pv. oryzae) ras III, IV, dan VIII. Bul Plasma Nutfah 19 (2): 53-60. DOI: 10.21082/blpn.v19n2.2013.p53-60 [Indonesian]

Zuki ZM, Rafii MY, Ramli A, Oladosu Y, Latif MA, Sijam K, Ismail MR, Sarif HM. 2020. Segregation analysis for bacterial leaf blight disease resistance genes in rice "MR219" using SSR marker. Chil J Agric Res 80 (2): 227-233. DOI: $10.4067 /$ S0718-58392020000200227 